\title{
Balancing energy and environmental concerns: the case of the Kayraktepe dam, Turkey
}

Ö. Sever ${ }^{1}$, Ş. Tiğrek ${ }^{2}$, and N. Şarlak ${ }^{3}$

${ }^{1}$ Prosem Engineering Architectural Consultation, Ankara, Turkey

${ }^{2}$ Department of Civil Engineering, Middle East Technical University, Ankara, Turkey

${ }^{3}$ Department of Civil Engineering, University of Gaziantep, Gaziantep, Turkey

Received: 17 September 2012 - Accepted: 25 September 2012 - Published: 16 October 2012

Correspondence to: N. Şarlak (sarlak@gantep.edu.tr)

Published by Copernicus Publications on behalf of the European Geosciences Union.

The case of the Kayraktepe dam, Turkey

Ö. Sever et al.

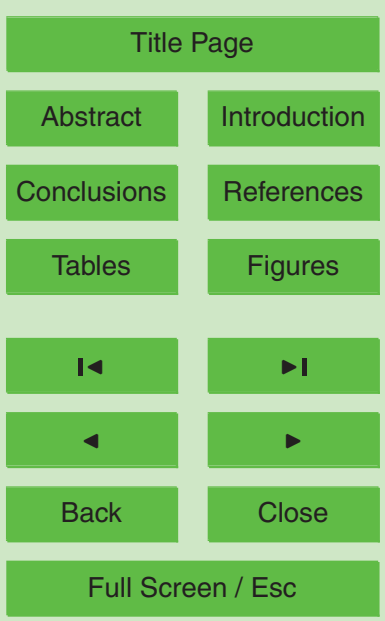

Printer-friendly Version

Interactive Discussion

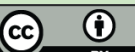




\section{Abstract}

In this study, an alternative solution for a large dam, namely the Kayraktepe Dam in Turkey, is investigated. The dam was planned for flood control, energy generation and flow regulation for a downstream irrigation project more than $30 \mathrm{yr}$ ago, but until now 5 the project has not begun due to it receiving severe criticism about environmental and social considerations. The project formulation was redeveloped several times in the past but the options were not found to be feasible. In this study, a detailed analysis of the available feasibility studies is provided and then a new formulation, consisting of the proposed one medium dam and five run-of-river type hydropower stations instead of a 10 large scale dam, is evaluated. The new formulation is equivalent to the existing project in terms of energy production and flood control. On the other hand, there are some benefits relative to other configurations as solutions to some of the environmental and social problems being addressed.

\section{Introduction}

15 The idea of building a dam on the Göksu River was proposed more than $30 \mathrm{yr}$ ago. After severe flooding along the river, the Kayraktepe project was designed to control floods, to produce energy and to supply irrigation water in 1982, as a $125 \mathrm{~m}$ high large dam. Four different dam locations were studied and finally a rock-fill dam with vertical clay core was chosen as an optimum (Hayashi, 1982). Thenceforth, an international competitive bidding process was initiated and the project was awarded. The World Bank provided loan guarantees of around two hundred million dollars. After the World Bank, Japanese, European and Arab Commercial Banks also provided loans amounting to three hundred fifty million dollars. The implementation of the projects under the investment program was started in 1986, however the World Bank decided not to support the project further after due considerations. The limited funds supplied by the World Bank was used for preliminary works such as camp facilities and access roads. In general,

HESSD

9, 11769-11789, 2012

The case of the

Kayraktepe dam, Turkey

Ö. Sever et al.

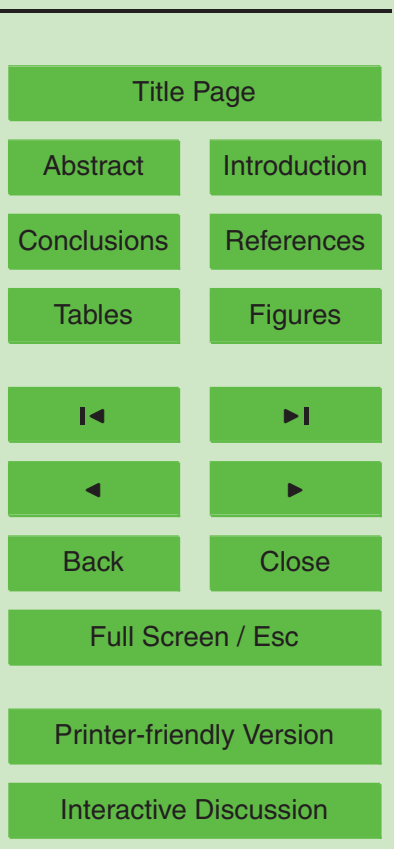

Interactive Discussion 
the concerns regarding the impacts of Kayraktepe Dam can be given under two main headings:

- Environmental: The Kayraktepe Dam will have negative effects on the river both upstream and downstream. There are several endemic species in the dam lake area. The Göksu Delta is located downstream from the site which is recognised as a Ramsar site. The dam will cut off sediment supply to the area downstream, which eventually leads to loss of fertility and long term coastal erosion.

- Social: Over the years the area has been heavily populated by people and the main economic activity is agricultural, tourism and husbandry.

10 The implementation and the commencement of the construction were not on the agenda till 1990s. In 1997, the Kayraktepe Dam and the HEPP Project were revised to reduce the height of dam due to remarkable development of social infrastructures and private properties in the project area (Sever, 2010). Under such circumstances the feasibility of a scheme of the project was reconsidered and a revised report was prepared were and only the height of the dam was lowered by $35.50 \mathrm{~m}$.

In 2000, the infamous report of World Commission on Dams (WCD) concluded that water infrastructure projects, including hydropower schemes, had "too often" been developed at an environmentally or socially unacceptable cost (WCD, 2000). It is the biggest victory of environmentalist and nongovernmental organizations against large dams. In the report, five core values were identified and twenty-six guidelines were listed for the construction of large dams. Turkey and some other developing economies placed strong criticism on the report, claiming that they had the right to economic development. However, from that time onwards, the construction of large dams became difficult due to actions taken by international credit agencies. More comprehensive scientific studies have followed showing the influence of large dams on the surrounding environment, social and climate (Hwang et al., 2007; Hossain, 2010; Wildi, 2010; Degu et al., 2011).

\section{HESSD}

The case of the Kayraktepe dam, Turkey

Ö. Sever et al.

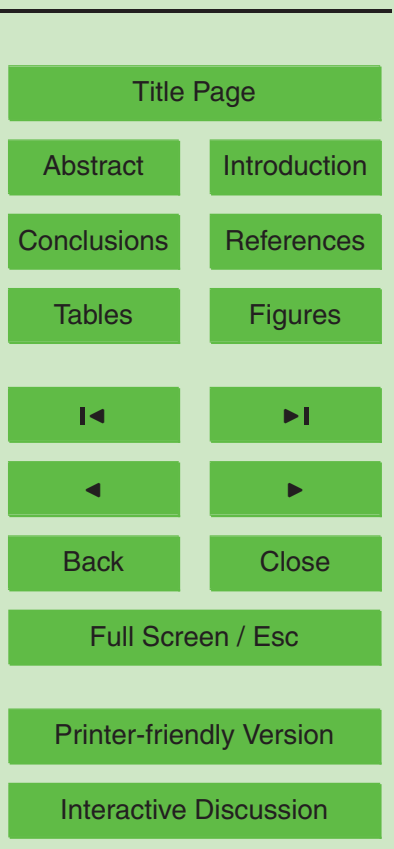

Interactive Discussion 
Eventually, the energy market was liberalised in Turkey. "Regulation about Procedures and Principles for Contract Agreements in Water Usage Rights for Production in Electricity Market" was published in Official Gazette of Republic of Turkey with number 25150 on 26 June 2003 (MENR, 2003). This regulation is one of the most important 5 milestones for the generation and the distribution of electricity in Turkey. Contractual matter of water usage rights have been edited with the publication of June 2003. The aim of this regulation can be summarised as to meet growing demand of electricity in Turkey by the involvement of the private sector, which is more competitive and faster than governmental organizations. A change has been made in the Contract Agree10 ments in Water Usage Rights Regulation on 25 May 2004. With this change, six ongoing Hydroelectric Power Plant construction projects were transferred to the private sector.

Thus in 2003, through the Water Use Right Agreement, the private sector took its place in energy generation. In 2008, the Kayraktepe Dam and HEPP Project were 15 awarded to a private company for a large scale dam formulation. However, the Kayraktepe project was redesigned by the private company in 2010 by changing the formulation to one medium dam and five regulators instead of a large scale dam (Sever, 2010).

Table 1 presents a chronology of the development plan of the Göksu Basin and the 20 Kayraktepe project along with important national legislations related to water resources projects, inauguration dates of administrations related to water resources projects, and important international developments related to water resources project. It is seen from the chronology that the project has been changed several times. Therefore, in order to eliminate possible misunderstanding, the original formulation, the revised project and newly developed project are named as Kayraktepe-1982, Kayraktepe-1997 and Kayraktepe-2010, respectively, within this article.

In the present article, an alternative solution for the Kayraktepe Dam consisting of the proposed one medium dam and five run-of-river type hydropower stations (Kayraktepe2010 ) instead of a large scale dam is evaluated.

\section{HESSD}

9, 11769-11789, 2012

The case of the

Kayraktepe dam, Turkey

Ö. Sever et al.

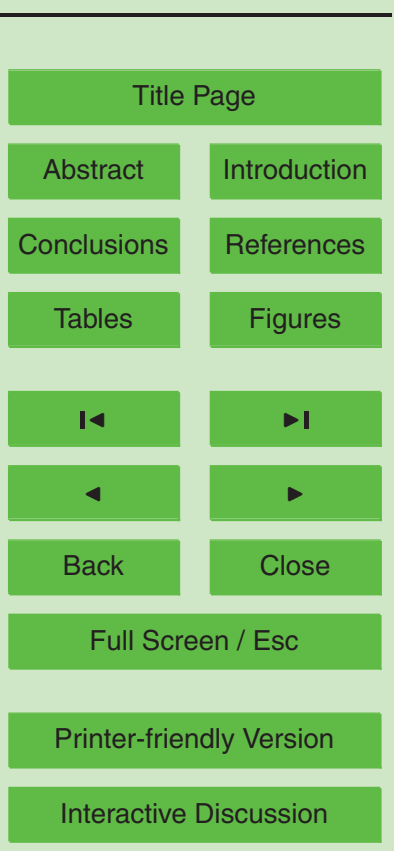




\section{General characteristics of the basin}

Göksu River is an important river system discharging into the Mediterranean Sea. There are two main tributaries of the river, namely Ermenek Creek and Göksu Creek. While flowing to the southeast, another two small streams (Hocasait Stream and Kurt5 suyu) join the river. It has a total length of $260 \mathrm{~km}$ and a drainage basin of about $10000 \mathrm{~km}^{2}$. It discharges into the sea near Silifke where the Göksu Delta Plain developed due to the sediment carried by the river.

The Kayraktepe Dam and HEPP project is located on $80 \mathrm{~km}$ west of Içl Province and extended between $\left(33^{\circ} 15^{\prime} \mathrm{E}, 34^{\circ} 15^{\prime} \mathrm{E}\right)$ longitude and $\left(36^{\circ} 15^{\prime} \mathrm{N}, 37^{\circ} 00^{\prime} \mathrm{N}\right)$ latitude

within the Eastern Mediterranean region (see in Fig. 1). There are two plains being considered worth mentioning. One is the Mut plain on the north, and the second is the Silifke plain on the south. Figure 1 shows the location of the basin and a plan view of Göksu River system.

The dam site is characterised geologically by the following features: thick alluvium 15 in the riverbed, high permeability of conglomerate, especially of the right abutment and major fault and sheared zone at the bedrock. Turkey is situated on the Alpine - Himalayan Earthquake Belt, and influenced the Alpine structure of Mediterranean Europe. Although, a fair amount of earthquake activity is observed, the most of the project area is situated within the earthquake free or less important zone. The climate of the project area exhibits typical Mediterranean characteristics as dry and hot summers, and mild and rainy winters. Annual average temperature at Silifke and Mut are $19^{\circ} \mathrm{C}$ and $17.2^{\circ} \mathrm{C}$, respectively. Annual average precipitation at the dam site is around $600 \mathrm{~mm}$ and most of the snowfall occurs from November to March.

The population of the project area is around 20000 (Cernea, 1991). It is observed 25 that in rural area, the population tends to increase very slowly or even to decrease in some years. But on the other hand, in the urban centres, the population is increasing at about $5 \%$ a year. This shows that there has been a strong tendency of immigration from rural areas to urban centres in recent years.

\section{HESSD}

9, 11769-11789, 2012

The case of the

Kayraktepe dam, Turkey

Ö. Sever et al.

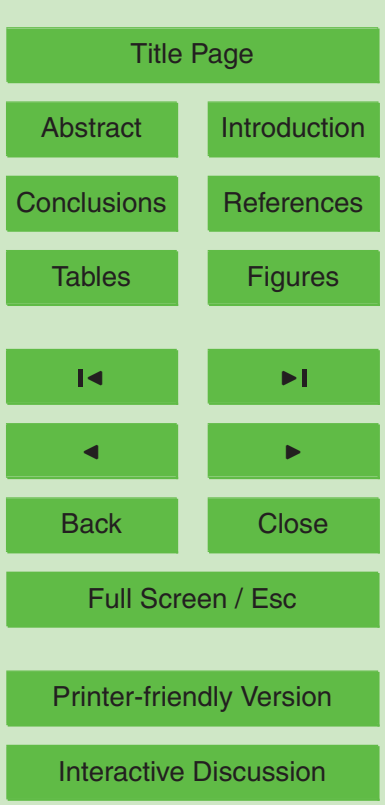




\section{General characteristics of the projects}

In 1997, the previous feasibility report was revised. The basic idea and typical section of the dam were not modified in the final design report in 1982 except for the dam height. In this revised feasibility, it was concluded that the dam be lowered by $35.50 \mathrm{~m}$; this

5 was economically more advantageous than the original project. The reservoir area was decreased from $133 \mathrm{~km}^{2}$ to $65.25 \mathrm{~m}^{2}$, whereas the installed capacity of the project was decreased from $200 \mathrm{MW}$ to $145 \mathrm{MW}$. In Kayraktepe-2010, the project was disintegrated into smaller projects. The plan view of this newly developed formulation is given in Fig. 2 and salient features of the new project are summarised in Table 2.

10 4 Evaluation of new formulation

\subsection{Energy production}

Environmental damage has not been included in cost-benefit analysis of early hydroelectric power projects as in the case of the Kayraktepe project.

The official cost-benefit analyses were carried out for the Kayraktepe project ignor15 ing the project's external costs and only including construction and operational costs. When its external costs are internalised, the net present value of the project falls below zero and the benefit-cost ratio decreases from 1.35 to 0.84 , indicating that the project is economically undesirable and the decision for its construction needs to be reconsidered (Biro, 1998). Biro (1998) studied Kayraktepe-1982 project's cost estimations with a more complete and informed economic analysis to estimate some of the local environmental and social costs of the project, and to incorporate these values into the project's cost-benefit analysis. Three major external costs were considered in cost-benefit analysis. These are the loss of agricultural income from the existing fields and trees in the reservoir area, the loss of value from the national forests which will

\section{HESSD}

9, 11769-11789, 2012

The case of the

Kayraktepe dam, Turkey

Ö. Sever et al.

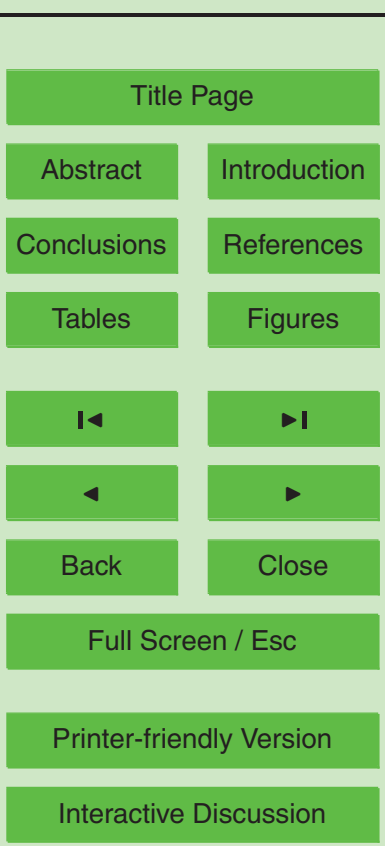


be inundated, and the non-use values placed on the environment by the local people (Öztürk, 2011).

The benefits of a possible large dam (Kayraktepe-1997) and new formulations (Kayraktepe-2010) were calculated and given in Table 3. It was found that the cost 5 benefit ratio of new formulation is satisfactory, although the total energy production will decrease.

\subsection{Analyses of the flood control function}

The principle objective of the flood control dam and the reservoir is to protect downstream communities. For this reason, the flood hydrographs of 50,100, 500, 1000 and $10000 \mathrm{yr}$ return period for the Kayraktepe dam were calculated. For this purpose, firstly the flood hydrograph of the Ermenek Dam, the Gezende Dam, the sub-basin between these dams, the Göksu Creek and the Kayraktepe Dam were obtained by daily average and annual peak flow records of stream gauging stations (SGS). Since the construction and operation starting time of the Mut Dam is unknown, through the planning phase the studies were prepared for both the cases as in operation or not. The outflow hydrographs of the Kayraktepe Dam were obtained from inflow hydrographs and flood routing studies. It should be emphasised that the same hydrological methodologies with the aforementioned feasibility reports were used in this study to make the comparison on an equal basis. However, the hydrological studies of the whole basin, which can be found in detail in Sever (2010), were revised. Firstly, the utilised flow data were updated. While the flow data until 1989 were used in the Kayraktepe 1997 report, the flow data were extended up to the year 2007 in the present study. Then, the characteristics of the projects within the basin were updated. In Kayraktepe 1997 report, the Ermenek Dam's characteristics were taken from the previous feasibility report. In the 25 report, Ermenek Dam's flood storage was given as $160.68 \mathrm{hm}^{3}$. But actually, Ermenek Dam was constructed with flood storage of $298.85 \mathrm{hm}^{3}$. The differences between two projects are listed in Table 4 briefly.

HESSD

The case of the Kayraktepe dam, Turkey

Ö. Sever et al.

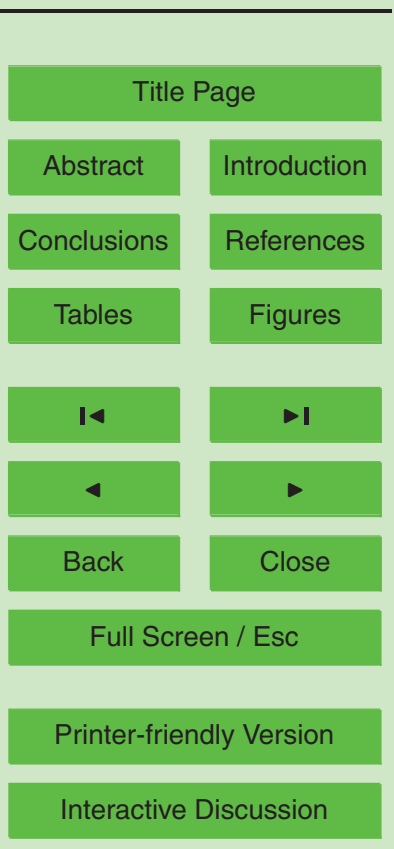

Interactive Discussion 
The peak value of the Kayraktepe Dam for a $500 \mathrm{yr}$ return period flood, in case the Mut Dam is not in operation, was calculated as $2363.95 \mathrm{~m}^{3} \mathrm{~s}^{-1}$ and the volume of the flood was calculated as $2351.42 \mathrm{hm}^{3}$. Actually, the basin should be re-examined by more advanced techniques as mentioned in Şarlak (2012). The Kayraktepe Dam 5 flood routing studies were done by using the volume-area curve and the $500 \mathrm{yr}$ return period inflow flood hydrograph. According to flood routing studies, in the case that the Mut Dam is in operation, the needed volume to limit the outflow discharge calculated as $1200 \mathrm{~m}^{3} \mathrm{~s}^{-1}$ was $104.73 \mathrm{hm}^{3}$. This value is accepted as the permissible outflow peak discharge of the proposed alternative dam.

10 The results of these hydrological studies show that a smaller dam (like the dam height in the newly developed formulation) is also enough to limit the outflow peak. With this newly developed formulation, the outflow peak discharge could be decreased to $1200 \mathrm{~m}^{3} \mathrm{~s}^{-1}$ for a $500 \mathrm{yr}$ return period flood. This discharge can flow inside Silifke District harmlessly.

A desire to control bigger floods with a large scale dam, resulted in a bigger area of land lost to the reservoir, which will lead to the inundation of largely populated areas upstream. Although the reservoir area is one of the crucial environmental and social variables, it has not commonly been allocated much importance. Thus, upstream rights should not be ignored when deciding the dam format. The people upstream from the site are living and producing their needs in their natural habitats. A bigger dam will force them to migrate downstream and they will not be as productive as before. We are responsible for minimizing the construction dam's adverse environmental and sociocultural impacts rely on assessing trade-offs and on managing risks. Hence, we should take lessons learned from resettlement practise and other effects of large dams dis-

\section{HESSD}

9, 11769-11789, 2012

The case of the

Kayraktepe dam, Turkey

Ö. Sever et al.

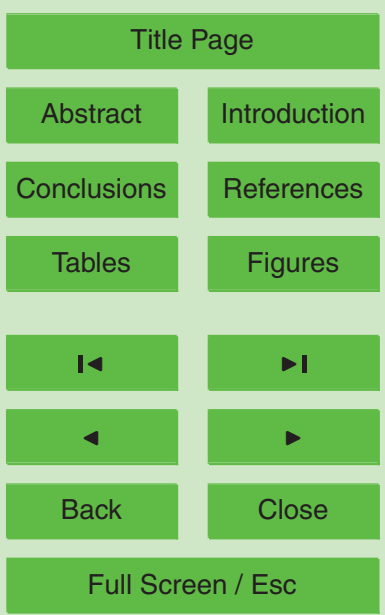

Printer-friendly Version

Interactive Discussion 


\subsection{Environmental considerations: analyses of the evacuation of sediments from reservoir by flushing}

The dam practise in Turkey shows that the accumulated sediment in the reservoir lakes behind a dam is only considered while calculating the economic life of the reservoir, 5 which is taken as approximately $50 \mathrm{yr}$ in Turkey. In this approach, environmental and social issues are only included at the initial stage of the project and any change over the operation and maintenance period is not included (Tiğrek and Aras, 2011). However, to design a dam with appropriate sediment management may be crucial for downstream ecology.

10 Poulos and Collins (2002) examined 69 rivers out of 169 in the Mediterranean drainage basin and concluded that construction of hundreds of dams around the Mediterranean Sea, especially over the last $50 \mathrm{yr}$, has led to a dramatic reduction of approximately $50 \%$ of the potential (natural) sediment supply. Such a reduction is considered to be the primary factor responsible for the loss of coastal (mainly deltaic) land, with annual rates of erosion ranging from tens to hundreds of meters.

There are a limited number of studies examining damming factor of coastal erosion on the coast line of the Mediterranean Sea in Turkey (Çetin et al., 1999; Tiğrek et al., 2008). Çetin et al. (1999) examined the Seyhan, Ceyhan and Göksu basin located in the northeastern Mediterranean where the most active shoreline changes have been occurring (Çetin et al., 1999). They indicated that the construction of the dams have an irreversible effect on the erosion of the deltas on the Mediterranean through inspecting the Ceyhan and Seyhan Rivers. It was observed greatly reduced sedimentation in the delta and erosion started at a rate of $24696 \mathrm{~m}^{2} \mathrm{yr}^{-1}$ on the mouth of the Seyhan due to construction of the Seyhan Dam on the river in 1954. As a result, from 1954 to 251995 , an area of about $1012536 \mathrm{~m}^{2}$ has been lost due to coastal erosion, and the delta became retrogradational. On the mouth of the Ceyhan River to the northeast, an area of $835779 \mathrm{~m}^{2}$ was eroded by the sea due to no sediment influx on the abandoned Ceyhan River channel in Yumurtalık Bay between 1948 and 1995. The total amount
HESSD

9, 11769-11789, 2012

The case of the

Kayraktepe dam, Turkey

Ö. Sever et al.

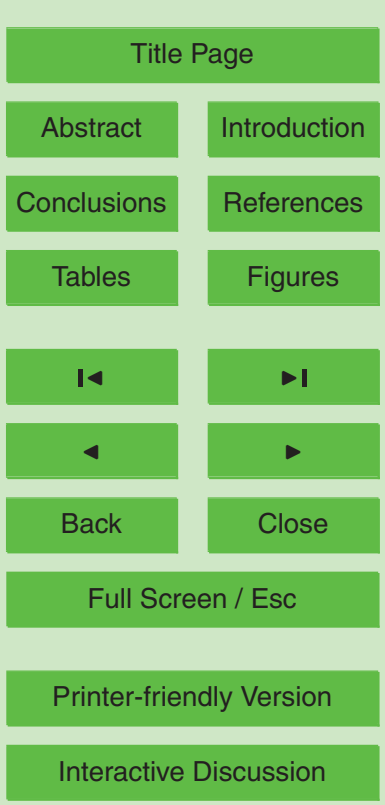


of progradation, from 1956 to 1995 , on the mouth of the Göksu River is $398445 \mathrm{~m}^{2}$. However, there is erosion on the southwest at a rate of $4548 \mathrm{~m}^{2} \mathrm{yr}^{-1}$ from 1951 to 1995. The reason for the erosion is not due to damming but to changing of the flow pattern of the Göksu River. The total amount of retrogression here is about $200125 \mathrm{~m}^{2}$. The 5 annual sediment amount at the Kayraktepe Dam axis was calculated as $1.13 \times 10^{6} \mathrm{~m}^{3}$. Since the dams are having a significant impact on sediment loads in the river (Palmieri et al., 2001; Işık et al., 2006; Lu and Siev, 2006; O'Reilly and Silberblatt, 2009; Bangqi Hu et al., 2009), the amount of retrogression will accelerate if a dam is constructed without sediment management facilities.

10 In fact, the coming sediments in the region can be transferred downstream before subsiding and solidifying during the flood period by means of flushing through the bottom outlets (Aras, 2009; Tiğrek and Aras, 2011).

The suitability of flushing can be examined by using Basson's Diagram (Basson and Rooseboom, 1997). The results for both the Kayraktepe-2010 and the Kayraktepe151997 formulations are summarised in Table 5 . In the table, $K_{\mathrm{w}}\left(=C_{0} / \mathrm{MAR}\right)$ and $K_{\mathrm{t}}$ $\left(=C_{0} / \mathrm{MSY}\right)$ are the ratios of storage $\left(C_{0}\right)$ to mean annual river runoff (MAR) and storage to mean annual sediment yield (MSY), respectively. According to Basson's Diagram, seasonal flushing is suggested in regions where $K_{\mathrm{w}}$ value is between 0.03-0.2. On the other hand, there will be excess water for flushing in the lower part of the diagram 20 where $30<K_{\mathrm{t}}<100$ (Tiğrek and Aras, 2011). It was found that the Kayraktepe-1997 is not suitable for flushing; however, the Kayraktepe-2010 is suitable for seasonal flushing.

\section{Conclusions}

The development of the land and water resources and total hydropower potential of the country have been on the agenda in Turkey since the early decades of the Republic. In order to combat fluctuations of the annual flows of many large basins throughout the year and over the years, the state has given priority to developing large-scale projects

\section{HESSD}

9, 11769-11789, 2012

The case of the

Kayraktepe dam, Turkey

Ö. Sever et al.

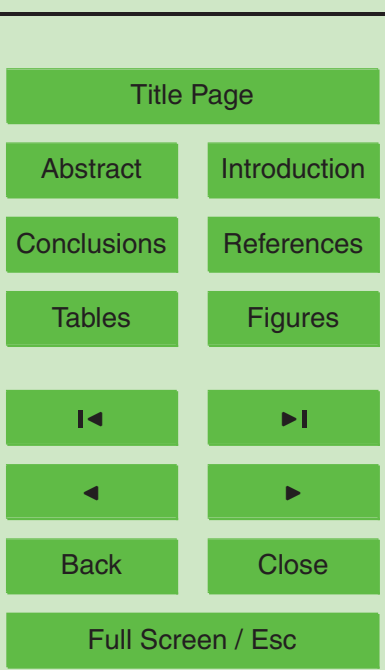

Printer-friendly Version

Interactive Discussion 
(Tiğrek and Kibaroğlu, 2011). On the other hand, the public awareness for environmental protection has increased all around the world as well as in Turkey. Thus, cumulative environmental impacts of a large scale dam on the Göksu River need to be assessed, not only in the vicinity of the dam but river deltas downstream of the dam and river-flow dependent wetlands (Scheumann et al., 2011).

We found that a discussion on large scale formulation of the Kayraktepe Dam is very beneficial in the context of balancing energy and environmental concerns. Thus, an alternative solution consisting of one dam and five run-of-river type hydropower stations is proposed and evaluated through comparison with the large dams in terms 10 of energy production and flood control.

The most important advantages of this new formulation can be summarised as

- a very large area containing numerous villages and valuable agricultural areas that were originally marked for expropriation and flooding will be preserved. A dramatic reduction in expropriation area by $83.5 \%$ (down to $16.5 \%$ of original) has been attained, where originally a 5000 ha area has been reduced to approximately 820 ha;

- the citizens living in the region will not be affected owing to significantly reduced expropriation;

- the Wild Life Protection Area to be flooded as per original formulation will be retained;

- the Göksu River Delta that, under the original formulation, would have been deprived of natural sediment inflow will now be completely preserved.

As a conclusion, an entirely renewable and environmentally compliant hydroelectric development yielding flood control and energy production will be realised through this formulation, with the replacement of a large dam by smaller units. The decision makers should consider these advantages for long term sustainable water management in Turkey.

\section{HESSD}

9, 11769-11789, 2012

The case of the

Kayraktepe dam, Turkey

Ö. Sever et al.

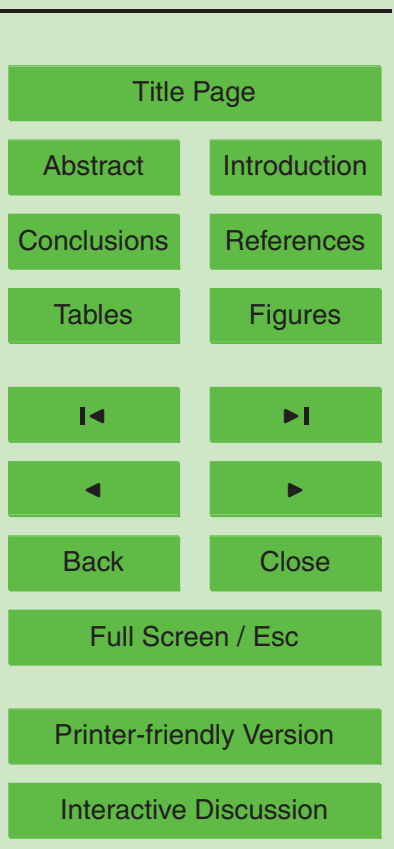

Interactive Discussion 


\section{References}

Aras, T.: Cost Analysis of sediment removal techniques from reservoir, Ms Thesis, Dept. of Civil Engineering, Hydromechanics Laboratory, Middle East Technical University, Ankara, Turkey, 2009.

5 Bangqi Hu, Zuosheng Yang, Houjie Wang, Xiaoxia Sun, Naishuang Bi, and Guogang Li: Sedimentation in the Three Gorges Dam and the future trend of Changjiang (Yangtze River) sediment flux to the sea, Hydrol. Earth Syst. Sci., 13, 2253-2264, doi:10.5194/hess-132253-2009, 2009.

Basson, G.: Hydropower dams and fluvial morphological impacts - an African perspective, the United Nations Symposium on Hydropower and Sustainable Development, Beijing, China, 27-29 October 2004, 1-16, 2004.

Basson, G. and Rooseboom, A.: Dealing with reservoir sedimentation, SA Water Research Commission Research Report, South Africa, 1997.

Biro, Y. E. K.: Valuation of the environmental impacts of the Kayraktepe Dam/Hydroelectric Project, Turkey: An Exercise in Contingent Valuation, Ambio, 27, 224-230, 1998.

Cernea, M. M.: Using knowledge from social sciences in development projects, World Bank, Washington DC, Discussion paper 114, 1991.

Çetin, H., Bal, Y., and Demirkol, C.: Engineering and environmental effects of coastline changes in Turkey, Northeastern Mediterranean, Environ. Eng. Geosci., 3, 315-330, 1999.

Degu, A. M., Hossain, F., Niyogi, D., Pielke, R., Shepherd, J. M., Voisin, N., and Chronis, T.: The influence of large dams on surrounding climate and precipitation patterns, Geophys. Res. Lett., 38, L04405, doi:10.1029/2010GL046482, 2011.

Hayashi, S. (project manager): Göksu - Kayraktepe dam and hydroelectric power plant feasibility report, prepared by Electric Power Development Co. Ltd., Japan and Suiş Proje

25 Mühendislik Müşavirlik Ltd. Şti., Turkey, 1982.

Hossain, F.: On the empirical relationship between the presence of large dams and alteration in extreme precipitation, Natural Hazards Review, 11, 97-101, 2010.

Hwang, S. S., Xi, J., Cao, Y., Feng, X., and Qiao, X.: Anticipation of migration and psychological stress and the Three Gorges dam project, China, Soc. Sci. Med., 65, 1012-1024, 2007.

30 Işık, S., Sasal M., and Doğan, E. :Investigation of downstream effects of dams in the Sakarya River, J. Fac. Eng. Arc., 21, 401-408, 2006.

\section{HESSD}

9, 11769-11789, 2012

The case of the

Kayraktepe dam, Turkey

Ö. Sever et al.

\section{Title Page}

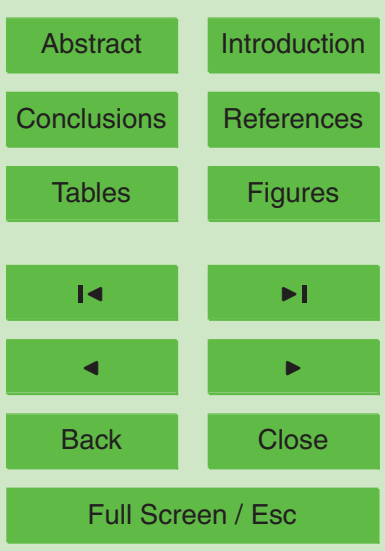

Printer-friendly Version

Interactive Discussion 
Lu, X. X. and Siew, R. Y.: Water discharge and sediment flux changes over the past decades in the Lower Mekong River: possible impacts of the Chinese dams, Hydrol. Earth Syst. Sci., 10, 181-195, doi:10.5194/hess-10-181-2006, 2006.

MENR (Ministry of Energy and Natural Resources of Turkey): The Procedures and principles 5 of signing water use right agreement for production activities in electricity market, published in Official Newspaper, No: 25150, 26 June 2003, 2003.

O'Reilly, C. and Silberblatt, R.: Reservoir management in Mediterranean climates through the European water framework directive, Water Resources Center Archieves, Hydrology, University of California, 2009.

10 Öztürk, A.: Sustainability assessment of a hydropower project: A case study of Kayraktepe Dam and HEPP, M.Sc. Thesis, Dept. of Civil Engineering, Hydromechanics Laboratory, Middle East Technical University, Ankara, Turkey, 2011.

Palmierie, A., Shah, F., and Dinar, A.: Economics of reservoir sedimentation and sustainable management of dams, J. Environ. Manage., 61, 149-163, 2001.

Poulos, S. E. and Collins, M. B.: Fluviatile sediment fluxes to the Mediterranean Sea: a quantitative approach and the influence of dams, Geological Society, London, Special Publications, 191, 227-245, 2002.

Şarlak, N.: Flood frequency estimator with nonparametric approaches in Turkey, Fresen. Environ. Bull., 21, 1083-1089, 2012.

20 Scheumann, W., Baumann, V., Mueller, A. L., Mutschler, D., Steiner, S., and Walenta, T.: Environmental impact assessment in Turkish dam planning, Turkey's water policy: national frameworks and international cooperation, Springer-Verlang, Berlin Heidelberg, doi:10.1007/9783-642-1936-2, 2011.

Sever, Ö.: Kayraktepe dam and HEPP, environmentally acceptable alternative solution, M.Sc. Thesis, Dept. of Civil Engineering, Hydromechanics Laboratory, Middle East Technical University, Ankara, Turkey, 2010.

Tiğrek, Ş. and Aras, T.: Reservoir Sediment Management, CRC Press/Balkema, Leiden, The Netherlands, 2011.

Tiğrek, Š. and Kibaroğlu, A.: Strategic role of water resources for Turkey, Turkey's water policy 30 national frameworks and international cooperation, Springer-Verlag, Berlin Heidelberg, 2742, 2011.

Tiğrek, Ş., Göbelez, Ö., and Aras, T.: Technological Perspectives for Rational Use of Water Resources in the Mediterranean Region (Sustainable management of reservoirs and
HESSD

9, 11769-11789, 2012

The case of the

Kayraktepe dam, Turkey

Ö. Sever et al.

\section{Title Page}

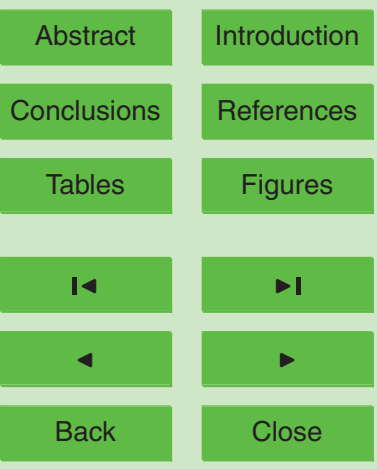

Full Screen / Esc

Printer-friendly Version

Interactive Discussion 
preserving water quality), Bari, Italy, IAM Bari: CIHEM (Centre International de Hautes Etudes Agronomiques Mediterraneenes), Seria A Semnaires Mediterranees, edited by: EI Moujabber, M., Mandi, L., Liuzzi, G. T., Martin, I. I., Rabi, A., and Rodriguez, R., No: 88, Options, ISSN: 1016-121X-ISBN: 2-8352-425-6, 2009.

5 WCD: Dams and development, a new framework for decision making, The report of the World Commission on Dams, Eartscan Publications Ltd, London and Sterling, November 16, ISBN: 1-85383-798-9 Paperback and 1-85383-797-0 hardback or available at: www.dams.org, 2000.

Wildi, W.: Environmental hazards of dams and reservoirs, Near Curriculum in Natural Environ-

\section{HESSD}

9, 11769-11789, 2012

\section{The case of the Kayraktepe dam, Turkey}

Ö. Sever et al.

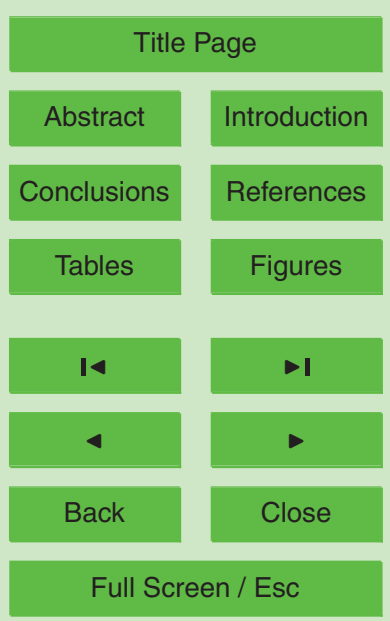

Printer-friendly Version

Interactive Discussion 


\begin{tabular}{|c|c|}
\hline Date & Event \\
\hline 1936 & $\begin{array}{l}\text { General Directorate of Electrical Power Resources Survey and Development Administration (EiE) was } \\
\text { founded to investigate issues on how rivers in the country could be utilised for energy production. }\end{array}$ \\
\hline 1953 & Initial investigation in the basin was started; Stream Gauging Stations were installed. \\
\hline 1954 & $\begin{array}{l}\text { State Hydraulic Works (DSi) was established. The basin scale studies for } 26 \text { hydrological basins have } \\
\text { been started. }\end{array}$ \\
\hline 1971 & Ramsar Convention or the convention of wetlands was accepted on 3 February 1971. \\
\hline 1977 & $\begin{array}{l}\text { The Kayraktepe Dam and HEPP project was identified by EIE. The contract awarded to the consortium } \\
\text { of EPDC, Su-Iss, Su-Yapi and TMB. }\end{array}$ \\
\hline 1979 & Construction of Gezende Dam on the Ermenek Creek was started. \\
\hline 1982 & The feasibility report of Kayraktepe Dam and HEPP project released. \\
\hline 1986 & $\begin{array}{l}\text { The construction of Kayraktepe Dam was awarded by DSI to EPDC under finance from the World Bank. } \\
\text { Small preliminary works done. }\end{array}$ \\
\hline 1990 & Construction of Gezende Dam was completed. \\
\hline 1994 & The Göksu Delta was recognised as Ramsar site as. Turkey ratified the Convention. \\
\hline 1997 & Kayraktepe Dam and HEPP Project was revised. \\
\hline 2000 & The World Commission on Dams published an infamous report as "Dams and Development". \\
\hline 2001 & $\begin{array}{l}\text { Act No: } 4628 \text { released: Aims to form a stable, transparent and competitive electricity market to generate } \\
\text { sufficient, sustainable and cheaper electricity. }\end{array}$ \\
\hline 2002 & Construction of Ermenek Dam was started. \\
\hline 2003 & Regulation for increasing involvement of private sector in the electricity market was established. \\
\hline 2004 & Six on-going HEPP developments were transferred to private sector. \\
\hline 2005 & Act No: 5346 released: Aims to increase electricity generation from renewable sources. \\
\hline 2006 & The construction of Blue Tunnel was started (water transmission from the Göksu River to Konya Plain). \\
\hline 2008 & $\begin{array}{l}\text { Kayraktepe Dam and HEPP were awarded to a private company. The company, namely BM holding } \\
\text { decided to revise the project in order to eliminate environmental effects. }\end{array}$ \\
\hline 2009 & Construction of Ermenek Dam was completed. \\
\hline 2011 & $\begin{array}{l}\text { Negotiations with DSi for the new formulation of Kayraktepe Dam and HEPP project were settled. This } \\
\text { project was rejected. Although this formulation is enough capable to prevent flood as well as economical } \\
\text { and sensitive for both environment and social, the DSI insisted on large scale dam formulation. }\end{array}$ \\
\hline 2012 & The project revision was restarted according to large scale dam formulation. \\
\hline
\end{tabular}

The case of the

Kayraktepe dam, Turkey

Ö. Sever et al.

Title Page

\section{Abstract}

Conclusions

Tables

14

4

Back

Full Screen / Esc

Printer-friendly Version

Interactive Discussion 


\section{HESSD}

Table 2. Salient features of Kayraktepe-2010 formulation.

\begin{tabular}{|c|c|c|c|c|c|c|}
\hline & $\begin{array}{l}\text { Kayraktepe } \\
\text { I Diversion } \\
\text { weir and } \\
\text { HEPP }\end{array}$ & $\begin{array}{l}\text { Kayraktepe } \\
\text { II Diversion } \\
\text { weir and } \\
\text { HEPP }\end{array}$ & $\begin{array}{l}\text { Kayraktepe } \\
\text { III Diversion } \\
\text { weir and } \\
\text { HEPP }\end{array}$ & $\begin{array}{l}\text { Kurtsuyu } \\
\text { Diversion } \\
\text { weir and } \\
\text { HEPP }\end{array}$ & $\begin{array}{l}\text { Kayraktepe } \\
\text { Dam and } \\
\text { HEPP }\end{array}$ & $\begin{array}{l}\text { Kayraktepe } \\
\text { IV Diversion } \\
\text { weir and } \\
\text { HEPP }\end{array}$ \\
\hline Location & $\begin{array}{l}\text { Göksu River } \\
\text { and Ermenek } \\
\text { Creek }\end{array}$ & Göksu River & Göksu River & $\begin{array}{l}\text { Kurtsuyu } \\
\text { Creek }\end{array}$ & Göksu River & Göksu River \\
\hline Type of weir & $\mathrm{RCC}$ & $\mathrm{RCC}$ & $\mathrm{RCC}$ & $\mathrm{RCC}$ & - & $\mathrm{RCC}$ \\
\hline Thalweg Elevation (m) & 117.00 & 106.00 & 95.50 & 115.00 & 41.50 & 27.00 \\
\hline Operating Elevation (m) & 120.00 & 110.00 & 104.00 & 120.00 & 85.00 & 37.00 \\
\hline Flood Level (m) & - & - & - & - & 93.00 & - \\
\hline Dam Crest Elevation (m) & - & - & - & - & 94.50 & - \\
\hline Tailwater Elevation (m) & 110.00 & 104.00 & 85.00 & 85.00 & 37.00 & 28.30 \\
\hline Design Discharge $\left(\mathrm{m}^{3} \mathrm{~s}\right)$ & 227.00 & 232.00 & 237.00 & 8.00 & 369.22 & 369.30 \\
\hline Installed Power (MW) & 20.53 & 12.53 & 36.53 & 2.48 & 152.13 & 29.35 \\
\hline Energy Production (GWh) & 58.80 & 39.37 & 114.40 & 9.68 & 308.58 & 57.40 \\
\hline Length of Canal $(\mathrm{m})$ & - & - & 5925.00 & 2285.00 & - & - \\
\hline Length of Tunnel (m) & - & - & 513.95 & - & - & - \\
\hline Type of spillway & $\begin{array}{l}\text { uncontrolled } \\
\text { spillway }\end{array}$ & $\begin{array}{l}\text { uncontrolled } \\
\text { spillway }\end{array}$ & $\begin{array}{l}\text { uncontrolled } \\
\text { spillway }\end{array}$ & $\begin{array}{l}\text { uncontrolled } \\
\text { spillway }\end{array}$ & $\begin{array}{l}\text { controlled } \\
\text { spillway }\end{array}$ & $\begin{array}{l}\text { uncontrolled } \\
\text { spillway }\end{array}$ \\
\hline Head pond & - & - & + & + & - & - \\
\hline
\end{tabular}

\section{The case of the Kayraktepe dam, Turkey}

Ö. Sever et al.

Title Page

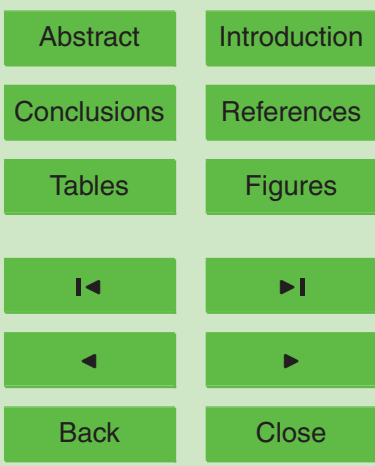

Full Screen / Esc

Printer-friendly Version

Interactive Discussion 


\section{HESSD}

9, 11769-11789, 2012

The case of the

Kayraktepe dam,

Turkey

Ö. Sever et al.

Table 3. Benefits for the dam formulations of Kayraktepe project (Sever, 2010).

\begin{tabular}{lrr}
\hline & 1997 Formulation & 2010 Formulation \\
\hline Firm Energy (Gwh) & 401.3 & 329.043 \\
Seconder Energy (Gwh) & 254.4 & 259.186 \\
Total Energy (Gwh) & 655.7 & 588.228 \\
Investment Cost $(\mathrm{TL})$ & 999119575 & 541829049 \\
Annual Income $\left(\$ \mathrm{yr}^{-1}\right)$ & 61504660 & 55175786 \\
Annual Outcome $\left(\$ \mathrm{yr}^{-1}\right)$ & 103789001 & 38896343 \\
Income/Outcome ratio & 0.59 & 1.42 \\
\hline
\end{tabular}

Title Page

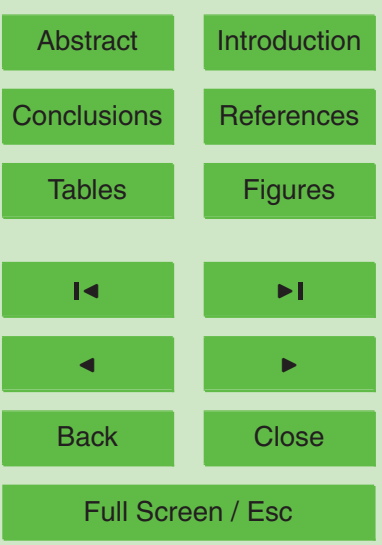

Printer-friendly Version

Interactive Discussion 


\section{HESSD}

\section{9, 11769-11789, 2012}

Table 4. Comparison table of the studies related to the flood calculations.

\begin{tabular}{l} 
Kayraktepe-1997 Project \\
\hline Flow data (SGS) till 1989 were used \\
\hline Ermenek Dam information was taken from \\
the previous feasibility report. In this report, \\
Ermenek Dam flood storage was given as \\
$160.68 \mathrm{hm}^{3}$. \\
The permissible outflow peak discharge of \\
the dam was given $800 \mathrm{~m}^{3} \mathrm{~s}^{-1}$. In that re- \\
port, $160 \mathrm{hm}^{3}$ storage was found to be ade- \\
quate.
\end{tabular}

Kayraktepe-2010 Project

Hydrology of the basin was revised. Flow data (SGS) till 2007 were used

Ermenek Dam information was revised (according to the real state). Ermenek Dam flood storage is $298.85 \mathrm{hm}^{3}$.

The permissible outflow peak discharge of the dam is accepted as $1200 \mathrm{~m}^{3} \mathrm{~s}^{-1}$. This value was taken from DSI - Adana Region. This value is also confirmed by calculating the water surface profile (HEC-RAS) in Silifke District.

But, according to the revised hydrology, this storage is adequate to decrease the peak outflow just to $1110 \mathrm{~m}^{3} \mathrm{~s}^{-1}\left(Q_{500}\right.$, In case the Mut Dam is in operation).

\section{The case of the Kayraktepe dam, Turkey \\ Ö. Sever et al.}

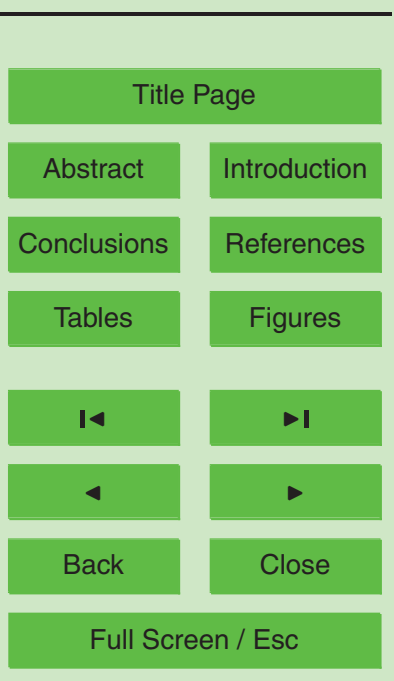

Printer-friendly Version

Interactive Discussion 


\section{HESSD}

9, 11769-11789, 2012

The case of the

Kayraktepe dam,

Turkey

Ö. Sever et al.

Table 5. The flushing coefficients for both formulations.

\begin{tabular}{lrr}
\hline & Kayraktepe-2010 Formulation & Kayraktepe-1997 Formulation \\
\hline$C_{0}\left(\mathrm{Mm}^{3}\right)$ & 174.50 & 1726.90 \\
MAR $\left(\mathrm{Mm}^{3}\right)$ & 3010.55 & 3010.55 \\
$\mathrm{MSY}\left(\mathrm{Mm}^{3}\right)$ & 1.13 & 1.13 \\
$K_{\mathrm{w}}$ & $174.50 / 3010.55=0.058$ & $1726.90 / 3010.55=0.573$ \\
$K_{\mathrm{t}}$ & $174.50 / 1.13=154.42$ & $1726.90 / 1.13=1528$ \\
\hline
\end{tabular}

Interactive Discussion 


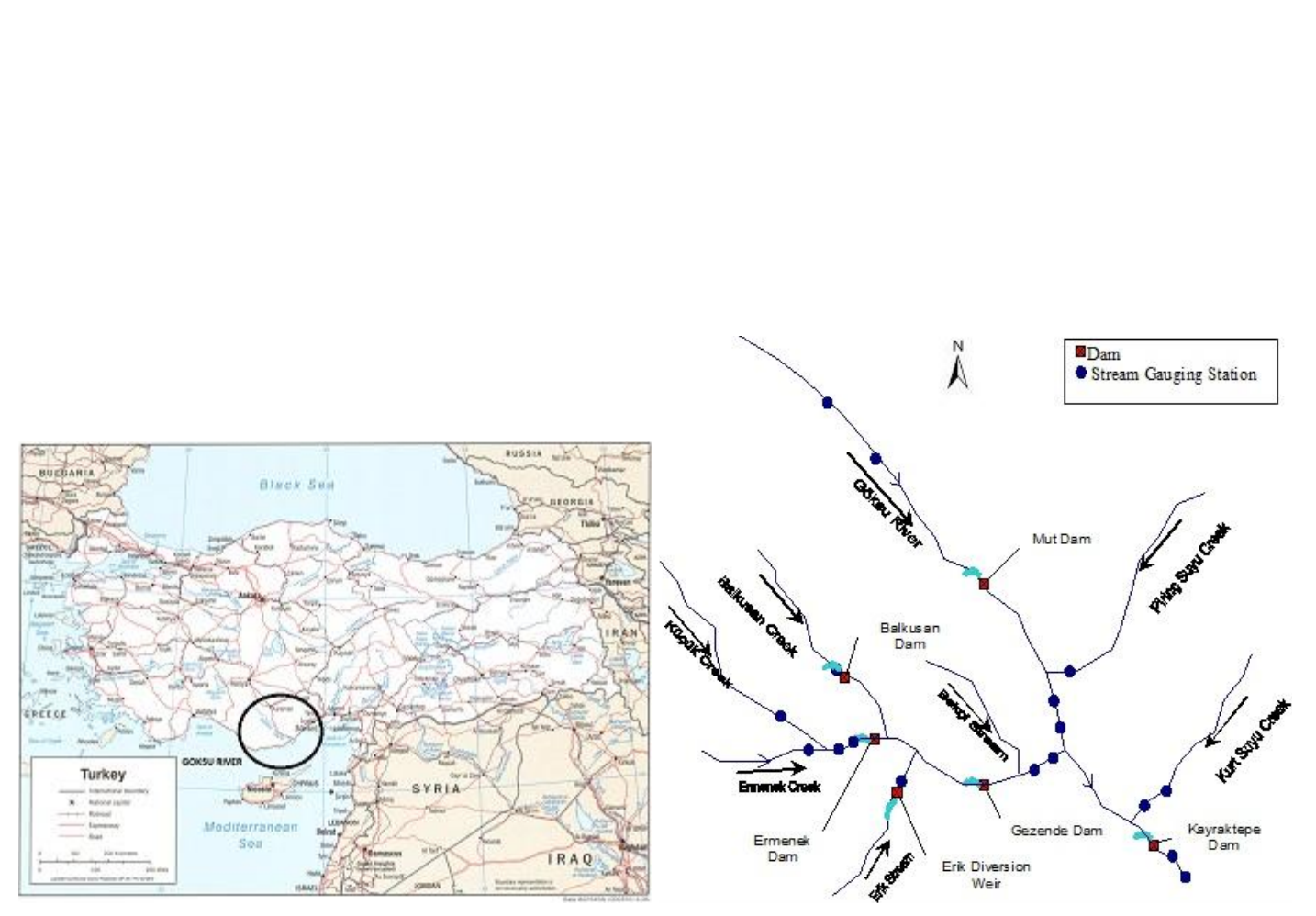

Fig. 1. The location of the Göksu river system and infrastructural development of Göksu Basin.

\section{HESSD}

9, 11769-11789, 2012

\section{The case of the Kayraktepe dam, Turkey}

Ö. Sever et al.

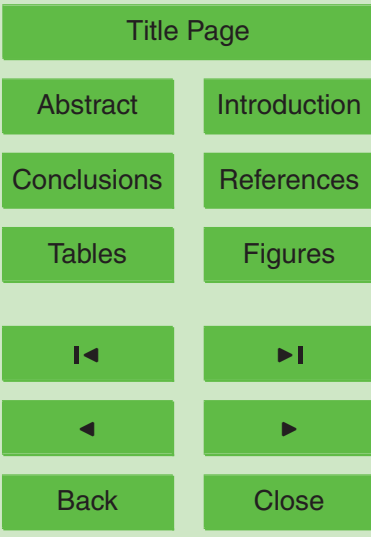

Full Screen / Esc

Printer-friendly Version

Interactive Discussion 


\section{HESSD}

9, 11769-11789, 2012

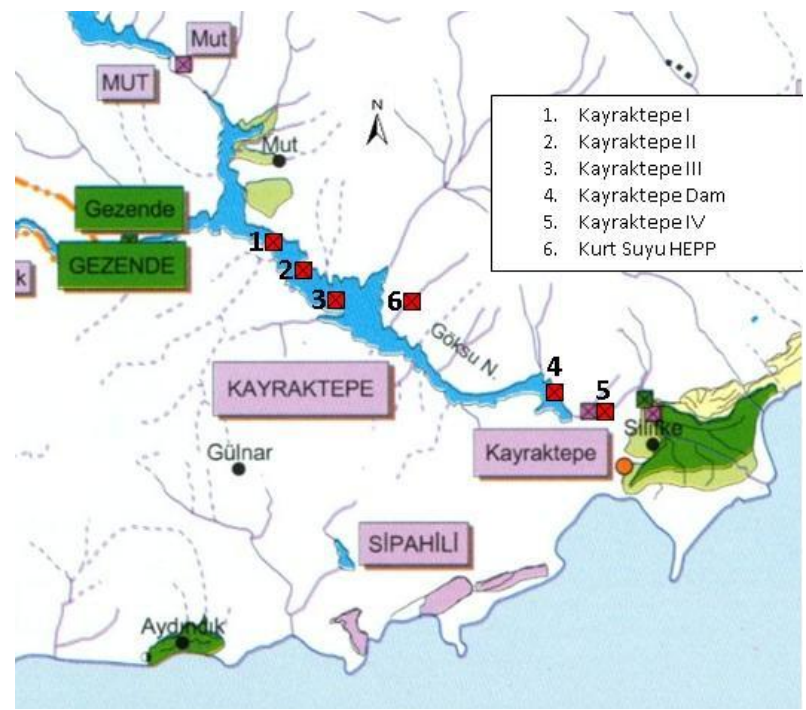

\section{The case of the Kayraktepe dam,} Turkey

Ö. Sever et al.

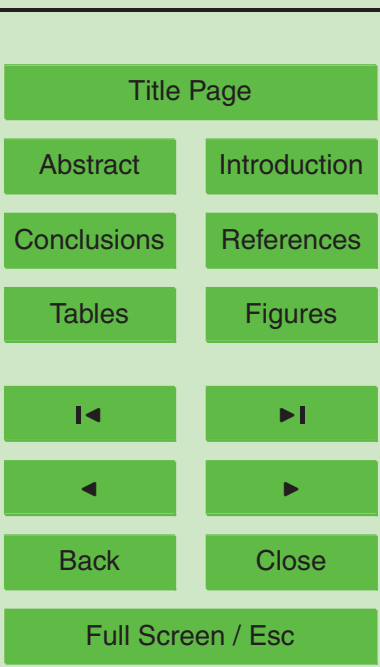

Printer-friendly Version

Interactive Discussion 